\title{
PERLINDUNGAN HUKUM TERHADAP WAJIB PAJAK YANG MENJUAL TANAHNYA DI BAWAH HARGA NILAI JUAL OBJEK PAJAK
}

\author{
Edwin Limy \\ Program Studi Magister Kenotariatan, Fakultas Hukum, Universitas Airlangga \\ e-mail: edwinlimy@yahoo.co.id
}

\begin{abstract}
ABSTRAK
Sumber penghasilan yang diperoleh negara yang besar adalah berasal dari pajak yang di antaranya adalah Bea Perolehan Hak Atas Tanah dan Bangunan (BPHTB) dan Pajak Penghasilan (PPh). Nilai Jual atas Objek Pajak (NJOP) yakni nilai yang lazimnya didapatkan pada suatu peristiwa jual beli yang timbul secara umum, apabila belum ada peristiwa jual beli maka NJOP dapat dihitung menggunakan perpaduan nilai dengan properti lain yang serupa sehingga diperoleh nilai perolehan baru atau NJOP pengganti. Pada prakteknya, semenjak NJOP menjadi dasar pengenaan pajak BPHTB dan/atau PPh, ditemukan berbagai persoalan, yakni apabila NJOP lebih besar dari nilai yang disepakati pembeli dan penjual. Konflik antara para pihak diharapkan dapat diselesaikan dengan cara litigasi dan non litigasi baik di Dirjen Pajak maupun Pengadilan Pajak. Penelitian ini bertujuan untuk menganalisa mengenai prinsip penentuan NJOP sebagai dasar pengenaan PPh dan BPHTB serta upaya hukum yang dapat ditempuh oleh wajib pajak yang merasa dirugikan dengan penghitungan tersebut. Penelitian yuridis normatif ini merekomendasikan adanya kebijakan hukum baru yang mengatur mengenai mekanisme penjualan tanah di bawah harga NJOP ataupun merevisi UU BHTB dan peraturan pelaksananya.
\end{abstract}

Kata Kunci: Pajak; BPHTB; Pajak Penghasilan; NJOP

\begin{abstract}
A large source of state's income was derived from taxes, which include fees for the acquisition of land and building rights (BPHTB) and income tax (PPh). Sales value of tax objects (NJOP) is the value obtained during a sale and purchase event that occurs in general, if there is no sale and purchase event, the NJOP can be calculated using a combination of values with other similar properties so that a new acquisition value or replacement of NJOP is obtained. In practice, since NJOP has become the basis for the imposition of BPHTB and / or PPh taxes, various problems have been occured, whic is if the NJOP is greater than the sales value. The conflict between the parties was expected to be resolved by litigation and non-litigation at the Directorate General of Taxes and the Tax Court. This study aims to analyze the principle of determining NJOP as the basis for the imposition of PPh and BPHTB as well as legal measures that can be taken by taxpayers who feel disadvantaged by the calculation. This normative juridical research recommends the existence of a new legal policy that regulates the mechanism for selling land below the NJOP price or revising the BHTB Law and its implementing regulations.
\end{abstract}

Keywords: Tax; PBHTB; Income tax; NJOP

\section{PENDAHULUAN}

Indonesia sebagai negara hukum yang menganut Pancasila dan bercirikan negara kesejahteraan modern bertujuan untuk menciptakan keadilan dan kesejahteraan bagi seluruh rakyat dan warga
Indonesia. Tugas Pemerintah dalam menciptakan tujuan tersebut salah satunya dengan melindungi hak-hak warga negara sebagai wajib pajak. Masalah hukum di bidang perpajakan mungkin dihindari bila 
Pemerintah dan warga negaranya mau mempelajari dan mematuhi peraturan pajak yang berlaku di Indonesia. $^{1}$

Pajak merupakan sumber perolehan negara yang hasilnya akan dimanfaatkan untuk melakukan pengembangan negara dengan maksud untuk kesejahteraan dan kemakmuran rakyat. Pembayaran dan pelaporan pajak dapat diartikan sebagai kewajiban hukum yang dilakukan oleh seluruh warga suatu negara terhadap negara sebagai bentuk turut serta bertanggung jawab dalam pengembangan dan kemajuan negara. $^{2}$

Pajak bumi dan bangunan merupakan salah satu bentuk pajak wajib yang dikenakan atas benda tak bergerak. Dalam pajak bumi dan bangunan, hal yang diutamakan yaitu objeknya dan karena sebab itulah situasi dan kapasitas seseorang atau badan yang dianggap menjadi subjek tidaklah memberikan pengaruh akan besarnya pajak karena itulah pajak ini dapat juga diartikan pajak yang obyektif. ${ }^{3}$ Penilaian Pajak Bumi dan Bangunan (PBB) ini akan terus meningkat jika tanah dan/atau bangunan itu berada dalam kawasan yang elit.

Pajak suatu daerah merupakan pajak yang dapat dibebankan oleh Pemerintah Daerah berdasarkan peraturan daerah yang berlaku di daerahnya, pajak yang dikenakan sesuai dengan peraturan nasional, tetapi besarnya perolehan nilainya hanya ditugaskan kepada Pemerintah Daerah, pajak yang dikenakan atau dimanajemenkan oleh Pemerintah, namun penarikannya dibagi hasilkan oleh Pemerintah Daerah. ${ }^{4}$ Seakan-akan wajib pajak dipaksa oleh Pemerintah Daerah untuk menjual tanah setara/lebih tinggi dari Nilai Jual Objek Pajak (NJOP). Padahal, NJOP di kawasan elit sangat tinggi, sehingga susah jika dijual setara atau di atas harga NJOP apalagi kalau properti berada di kawasan yang elit. NJOP menjadi tugas Pemerintah Daerah sehingga penentuan NJOP ini dilakukan oleh satu pihak

\footnotetext{
${ }^{1}$ Etty Rochaeti. (2012). "Perlindungan Hukum Bagi Wajib Pajak Dalam Penyelesaian Sengketa Pajak”. Jurnal Hukum, Vol. 26 No. 01. Bandung: Sekolah Tinggi Bandung, h. 497.

2 I. Kadek Sumadi dan Naniek Noviari. (2014). "Perlindungan Hukum Wajib Pajak Dalam Sengketa Pajak (Perspektif UU No. 14 Tahun 2002)". Jurnal Ilmiah Akuntansi dan Bisnis. Vol. 9 No. 2. Bali: Universitas Udayana, h. 122.

${ }^{3}$ Rochmat Soemitro. (1986). Pajak Bumi dan Bangunan. Bandung: Eresco, h. 5.

${ }^{4}$ J. Davey. (1988). Pembiayaan Daerah. Jakarta: UI Press, h. 39 .
}

saja sehingga tidak menutup kemungkinan adanya kesewenang-wenangan Pemerintah Daerah dalam menentukan NJOP tersebut.

NJOP adalah harga pada umumnya yang didapatkan pada peristiwa jual beli yang timbul secara lazim, NJOP dihitung berdasarkan pertimbangan harga dengan properti yang lainnya, nilai perolehan yang baru, atau NJOP pengganti. ${ }^{5}$ Dalam hal penjualan tanah di bawah harga NJOP terdapat banyak sekali permasalahan. Nilai pengalihan hak merupakan harga yang paling besar antara harga yang terdapat dalam Akta Pengalihan Kepemilikan terhadap NJOP properti yang bersangkutan. Jika menjual properti di bawah harga NJOP maka akan dipungut Pajak Penghasilan (PPh) dan BPHTB yang didasarkan pada NJOP bukan berdasarkan nilai jual belinya.

\section{PERUMUSAN MASALAH}

Berdasarkan latar belakang di atas, maka yang menjadi permasalahan ialah prinsip penentuan NJOP sebagai dasar pengenaan PPh dan BPHTB, serta upaya hukum wajib pajak terhadap penetapan BPHTB dan PPh atas pengalihan kepemilikan tanah dan bangunan di bawah NJOP.

\section{METODE PENELITIAN}

Pendekatan penelitian yang dipergunakan adalah pendekatan perundang-undangan (statute approach), dilaksanakan dengan memperhatikan seluruh peraturan dan regulasi yang terkait dengan pemecahan masalah artikel ini. Pendekatan yang kedua dipergunakan yaitu pendekatan konsep (conceptual approach) adalah suatu pendekatan atas penelitian hukum yang berangkat dari peraturanperaturan dan teori-teori yang bertumbuh di dalam pengetahuan hukum. ${ }^{6}$ Dalam mempelajari peraturan-peraturan dan doktrin-doktrin tersebut akan diperolehnya suatu gagasan yang baru sehingga menciptakan pemahaman hukum, persepsi hukum, dan landasan hukum yang sesuai dengan masalah yang ada, karena itulah akan menjadikan dasar yang kuat dalam mengembang dan memberikan

\footnotetext{
${ }^{5}$ Mardiasmo. (1998). Perpajakan. Yogyakarta: Andi Offset, h. 142 .

6 Peter Mahmud Marzuki. (2014). Penelitian Hukum. Cetakan IX. Jakarta: Kencana Prenada Media Group, h. 133.
} 
pendapat hukum supaya dapat dimanfaatkan untuk merampungkan masalah yang ada. ${ }^{7}$

\section{PEMBAHASAN}

\section{Subjek dan Objek Bea Perolehan Tanah dan Bangunan (BPHTB)}

BPHTB yaitu pengenaan pajak terhadap perolehan hak atas tanah dan bangunan, yang sesuai dengan Pasal 1 angka 1 Undang-Undang BPHTB. Dalam hal ini, yang dimaksud penggantian kepemilikan sehingga memperoleh hak atas tanah dan atau obyek bangunan yakni suatu kegiatan hukum yang dilaksanakan oleh wajib pajak atau peristiwa hukum yang terjadi sehingga membawa dampak didapatkannya hak atas suatu tanah dan atau obyek bangunan oleh perseorangan atau suatu badan sedangkan yang dimaksud hak atas tanah dan/ atau suatu bangunan merupakan hak atas suatu tanah yang termasuk Hak Pengelolaan, berikut juga yang terdapat di atasnya, sebagaimana terurai dalam UU No. 5 Tahun 1960 tentang Peraturan Dasar PokokPokok Agraria, UU No. 16 Tahun 1985 tentang Rumah Susun, dan peraturan-peraturan yang berlaku lainnya. ${ }^{8}$ BPHTB dapat juga dimasukkan ke dalam jenis pajak daerah yang diserap dan dikendalikan oleh Pemerintahan Daerah menjadi pendapatan asli atas daerah yang dapat dipergunakannya untuk membayar kegiatan Pemerintah Daerah dan pengembangan di daerahnya.

Menurut Pasal 4 Undang-Undang BPHTB, subjek BPHTB yakni personal atau badan yang dikategorikan dapat menerima hak atas tanah dan atau suatu bangunan. Sementara Pasal 2 UU No. 20 Tahun 2000 disebutkan bahwa yang dapat dijadikan tujuan dikenainya BPHTB adalah pengalihan kepemilikan hak atas tanah atau suatu bangunan, yang meliputi:

a. Pemindahan hak karena:

1. jual beli;

2. tukar-menukar;

3. hibah;

4. hibah wasiat, adalah penentuan wasiat yang secara terutama mengatur tentang pengalihan hak atas suatu objek tanah dan/atau bangunan terhadap perseorangan atau suatu badan hukum, yang diberlakukan sehabis yang

\footnotetext{
7 ibid., h. 135-136.

${ }^{8}$ Mardiasmo. op.cit., h. 340.
}

memberi hibah wasiat dipanggil oleh Yang Mahakuasa;

5. waris, adalah pendapatan/perolehan hak akan objek tanah dan atau suatu bangunan terhadap ahli waris dari pewaris, karenanya diberlakukan sehabis pewaris tersebut dipanggil Yang Maha Kuasa;

6. penghasilan akan suatu PT atau suatu badan hukum yang lainnya, adalah pengalihan kepemilikan hak atas objek tanah dan atau suatu bangunan dari seseorang atau suatu badan yang tertuju pada PT atau badan hukum lainnya, selaku pengikutan modal kepada PT atau badan yang lainnya;

7. peralihan yang disebabkan pemisahan hak, adalah peralihan sepenggal hak kepunyaan bersama atas objek tanah atau objek bangunan oleh seseorang atau suatu badan terhadap pemilik hak kepunyaan bersama;

8. penunjukan pembeli akan acara lelang, adalah penentuan jawara atas lelang yang dilakukan pejabat lelang yang telah dicantumkan dalam suatu risalah atas lelang;

9. implementasi atas putusan yang ditetapkan hakim yang berkekuatan hukum tetap, yaitu adanya perubahan suatu kepemilikan hak dari sendiri atau suatu badan hukum yang merupakan salah satu subjek terhadap subjek yang telah ditetapkan dalam suatu putusan hakim;

10. penggabungan usaha, adalah suatu peristiwa hukum untuk menjadikan satu dari dua (2) atau banyak badan usaha lewat jalan melikuidasi badan usaha lainnya yang bersatu dan memperjuangkan salah satu badan usaha;

11. peleburan usaha, adalah suatu peristiwa hukum yang menyatukan suatu usaha dari 2 atau banyak badan usaha lewat cara melikuidasi badan usaha yang ingin bergabung dan menciptakan badan suatu usaha yang terbaru;

12. pemekaran usaha, adalah sesuatu peristiwa hukum yang memisahkan badan suatu usaha, dijadikan beberapa badan atas usaha dengan jalan membuat suatu badan atas usaha yang terbaru dan melakukan peralihan sepenggal aktiva dan/atau pasiva yang 
ditujukan terhadap badan atas usaha yang terbaru didirikan itu dengan tidak adanya melikuidasi badan usaha yang dahulu;

13. hadiah, adalah sesuatu kejadian berbentuk pengalihan kepemilikan atas tanah dan atau objek bangunan yang diperbuat oleh seseorang atau badan hukum terhadap yang berhak atas anugerah;

b. Pemberian hak baru karena:

1. kelanjutan pelepasan hak, adalah pelimpahan hak baru atas tanah yang berasal dari pelepasan atas hak yang ditujukan kepada seseorang atau suatu badan hukum dari negara;

2. diluar pelepasan hak, adalah pelimpahan hak baru atas tanah kepada seseorang atau suatu usaha yang berbadan hukum dari pemegang hak milik atau dari Pemerintah menurut peraturan yang telah diberlakukan;

Pelaksanaan pungutan BPHTB yang berlaku di Indonesia dilakukan dengan berpegang pada 5 prinsip, yaitu: ${ }^{9}$

Pertama, Pelaksanaan akan suatu kewajiban Bea Perolehan Hak atas Tanah dan Bangunan adalah didasarkan pada sistem self assessment, yakni wajib pajak melakukan penghitungan dan melakukan pembayaran sendiri utang pajak yang dimiliki. Sistem self assessment diartikan sebagai sistem perpajakan negara kita yang diberlakukan sejak terjadinya perombakan perpajakan pada tahun 1983, dimana kepada wajib pajak diberikan kekuasaan/keyakinan untuk melakukan penghitungan, melakukan pembayaran, dan melakukan pelaporan atas besarnya pajak yang terutang. Aparat pajak memiliki tugas untuk melaksanakan bantuan dan pengawasan supaya wajib pajak dapat menjalankan kewajiban pajaknya secara tepat. Sistim self assessment ini, terutama pada BPHTB, sangat diyakini supaya subyek ini dapat memperoleh kemudahan guna memenuhi kewajiban pajaknya dan mengembangkan pemahaman pajak atas subjek pajak, terutama pajak yang muncul pada waktu peristiwa perolehan hak akan objek tanah dan objek bangunan.

Kedua, Besarnya suatu beban ditentukan senilai 5 persen dari NPOPKP. Dalam BPHTB, pajak yang

\footnotetext{
${ }^{9}$ Marihot Pahala Siahaan. (2003). Bea Perolehan Hak Atas Tanah dan Bangunan. Jakarta: PT RajaGrafindo Persada, h. 4547.
}

belum dibayar tidak dibebankan langsung atas NPOP yang dijadikan acuan penarikan pajak, tetapi wajib melakukan pengurangan terlebih dahulu terhadap NPOPTKP, yakni nilai yang sudah ditentukan dari NPOP yang belum dapat dibebankan pajak. Dalam hal ini dimaksudkan untuk asas keadilan bagi seluruh masyarakat yang mempunyai penghasilan tidak tinggi yang mendapat hak atas suatu tanah dan objek bangunan dengan NPOPTKP di atas NPOP yang ditentukan belum dapat dipungut pajak (bebas pajak), bagi para subjek yang mendapat properti dengan harga besaran perolehan NPOPTKP di bawah NPOP sehingga NPOP dimasukkan sebagai esensi dikenakannya pajak yang diharuskan terlebih dahulu dipotong menggunakan NPOPTKP.

Ketiga, Agar pengoperasian Undang-Undang BPHTB dilakukan secara tepat, kemudian kepada pejabat umum dan/atau kepada wajib pajak yang melakukan pelanggaran atau belum mau melaksanakan keharusannya yang dimana diatur oleh peraturan akan diberikan hukuman sesuai dengan peraturan-peraturan yang diberlakukan. Kondisi itu sepatutnya dibutuhkan untuk dijaminkannya suatu kepastian hukum dalam melakukan pungutan BPHTB supaya wajib pajak dan personel yang memiliki wewenang tidak melaksanakan suatu kesatanah dalam pelaksanaan kewajiban pajak.

Keempat, Hasil perolehan BPHTB adalah suatu perolehan negara yang tidak seluruhnya diberikan kepada pemerintah suatu daerah, untuk menaikkan keuangan daerahnya yang berguna membayar kegiatan pemerintah suatu daerah dan dalam kegiatan menjunjung tinggi otonomi suatu daerah.

Kelima, Seluruh penarikan pajak atas pendapatan hak atas objek tanah dan/atau bangunan yang melanggar peraturan BPHTB tidak diperbolehkan. Dengan terciptanya peraturan yang mengatur BPHTB maka BPHTB yakni satu-satunya pajak yang dapat dipungut atas pendapatan hak atas objek tanah dan objek bangunan di Indonesia karena itulah seluruh penarikan yang ada hubungannya dengan pendapatan hak (kecuali biaya yang harus dibayar berhubungan dengan penerbitan akta dan pendataan hak atas objek tanah dan suatu kontruksi yang sudah ditentukan sesuai dengan peraturan yang diberlakukan) tidak diperbolehkan dilaksanakan oleh subjek mana pun. Kondisi ini sangatlah penting supaya warga tidak dibebankan dengan penarikan yang tidak cocok 
dengan peraturan berhubungan dengan pendapatan suatu hak atas objek tanah dan bangunan yang didapatnya.

Besarnya pendapatan objek pajak disesuaikan berdasarkan suatu cara dipunyainya objek tanah dan/atau bangunan. Apabila objek tanah dan/atau bangunan didapatkannya dari: a. jual beli sehingga nilai pendapatannya yakni nilai transaksi; b. tukar menukar sehingga nilai pendapatannya yakni nilai pasar atas objek pajak; c. hibah, nilai pendapatannya yakni nilai pasar atas objek pajak; d. pemasukan dalam badan hukum, nilai perolehannya yakni nilai pasar atas objek pajak; e. pemisahan hak sehingga terjadinya suatu perubahan kepemilikan maka angka perolehannya yakni nilai pasar atas objek pajak; f. penunjukkan pembeli akan acara lelang, nilai pendapatannya yakni nilai transaksi yang terdapat di risalah lelang; g. peralihan hak karena dilaksanakannya putusan yang diterbitkan hakim yang berkekuatan hukum tetap, angka pendapatannya yakni nilai pasar atas objek pajak; h. pemberian hak yang baru terhadap tanah sebagai kesinambungan dari pelepasan suatu hak, angka pendapatannya yakni nilai pasar atas objek pajak; i. pemberian hak baru terhadap tanah di luar pelepasan hak, nilai pendapatannya yakni nilai pasar atas objek pajak. ${ }^{10}$

Besaran angka pendapatan terhadap target pajak ini harus disesuaikan terhadap harga peristiwa jual beli objek pajak. Jika NJOP lebih tinggi dari pada nilai yang ditransaksikan sehingga yang dipakai tetaplah nilai jual/beli yang yerjadi pada objek pajak tersebut. Tetapi jika angka jualnya terhadap objek pajak lebih banyak dari NJOP, sehingga yang dipakai yakni nilai jual/beli yang terjadi lewat peristiwa hukum terhadap objek pajak, yang telah disesuaikan dengan Pasal 6 ayat (3) UU BPHTB.

\section{Subyek dan objek pajak penghasilan (PPh) atas pengalihan tanah dan/atau bangunan}

Pada Pasal 2 ayat (1) UU No. 36 Tahun 2008 tentang pajak penghasilan menerangkan bahwa yang dapat dijadikan subjek dikenakannya pajak adalah:

Pertama, Orang Pribadi. Sebagai pihak yang dapat mempunyai domisili atau sedang berada di negara Indonesia mapun di luar negara Indonesia.

${ }^{10}$ Supramono dan Theresia Woro Damayanti. (2005). Perpajakan Indonesia Mekanisme dan Perhitungan. Yogyakarta: Andi Offset, h. 113.
Kedua, Warisan yang belum terlaksana pembagian menjadi satu kesatuan yang menggantikan empunya hak. Warisan yang belum dapat dibagi menjadi satu kesatuan dapat diartikan subyek pajak pengganti, meneruskan para pihak yang mempunyai hak yang merupakan ahli waris. Pemilihan warisan yang belum dilakukan pembagian sebagai subyek pajak yang dapat meneruskan hak pewaris yang ditujukan supaya pungutan pajak terhadap hasil yang diperoleh dari warisan yang dimaksud dapat dilaksanakan.

Ketiga, Badan. Badan adalah perkumpulan atas pihak dan/atau aset yang mempunyai makna kebersamaan antara yang melaksanakan suatu usaha atau yang belum melaksanakan suatu usaha antara lain BUMN, PT atau BUMD dengan sebutan atau dalam kondisi apapun, perseroan komanditer, kongsi, firma, dana pensiun, koperasi, persekutuan, yayasan, perkumpulan, organisasi sosial politik, organisasi massa, atau organisasi lainnya, dan bentuk-bentuk badan lainnya yang termasuk dalam kontrak investaasi kolektif dan bentuk usaha tetap. BUMN dan BUMD yaitu subyek hukum pajak yang tidak memerlukan mencermati namanya dan spesifikasinya, setiap bagian dari badan Pemerintah, contohnya badan, lembaga, dan sebagainya yang dipunyai oleh Pemerintah Daerah dan Pemerintah Pusat dalam melaksanakan akan usaha atau mengerjakan suatu keperluan untuk mendapatkan keuntungan yakni subjek pajak. Pada penafsiran persekawanan yang termasuk perhimpunan, asosiasi, persatuan, atau ikatan-ikatan dari pihak-pihak yang mempunyai maksud dan tujuan yang satu.

Keempat, Bentuk usaha tetap. Bentuk usaha tetap yakni suatu bentuk usaha yang dapat digunakan oleh seseorang yang belum mempunyai domisili di negara Indonesia, seseorang yang tinggal di negara Indonesia tidak lebih banyak dari 183 hari dalam ketetapan durasi, 12 bulan, dan badan usaha yang belum dijadikan/dibentuk dan belum mempunyai kedudukan di negara Indonesia untuk melaksanakan suatu usaha atau melancarkan suatu keperluan di negara Indonesia.

Dari penjelasan dalam UU PPh dapat mengetahui subjek dan objek pajak, tetapi ada Peraturan Pemerintah yang memberikan aturan lebih lanjut tentang pajak penghasilan dari beralihnya hak akan suatu objek tanah beserta bangunan. Dalam Pasal 
1 angka 1 PP No. 34 Tahun 2016 yang menjadi objek PPh adalah: Pertama, Beralihnya kepemilikan terhadap objek tanah dan/atau objek bangunan, yang dimaksud penghasilan dari beralihnya kepemilikan atas objek tanah dan/atau objek bangunan yaitu pendapatan yang didapatkan dari pihak yang melakukan pengalihan kepemilikan akan objek tanah dan/atau objek bangunan dengan cara tukar menukar, penjualan, penyerahan hak, pelepasan hak, hibah, lelang, pewarisan, atau cara lainnya yang telah disetujui oleh seluruh pihak terkait. Kedua, Perjanjian pengikatan jual beli atas objek tanah dan/atau objek bangunan beserta perubahannya.

Nilai pajak penghasilan dari perubahan kepemilikan atas objek tanah dan/atau objek bangunan itu berbeda-beda sesuai dengan Pasal 2 PP No. 34 Tahun 2016, yaitu:

Pertama, dua setengah persen pada jumlah bruto akan nilai pengalihan kepemilikan obyek tanah dan/ atau objek kontruksi kecuali penggantian kepemilikan hak atas obek tanah dan/atau objek bangunan berupa rumah yang tidak mewah atau apartemen yang tidak mewah dapat dilaksanakan oleh wajib pajak yang jenis kegiatan utamanya melaksanakan perubahan kepemilikan hak atas obyek tanah dan/atau objek bangunan.

Kedua, satu persen pada nilai jumlah bruto atas angka perubahan kepemilikan atas objek tanah dan/ atau suatu bangunan berupa tempat tinggal yang tidak mewah dan apartemen yang tidak megah yang telah dilaksanakan oleh subyek pajak yang kegiatan utamanya melaksanakan perubahan kepemilikan hak atas obyek tanah dan/atau objek bangunan.

Ketiga, nol persen atas perubahan kepemilikan hak atas obyek tanah dan/atau objek bangunan terhadap BUMN yang memperoleh perintah dari Pemerintah, Pemerintah, atau BUMD yang memperoleh perintah tertentu dari kepala suatu daerah, yang sesuai dengan peraturan yang memberikan aturan berisikan pengadaan tanah untuk pengembangan demi kepentingan masyarakat.

Pada penjelasan di atas, maka penjual yang menjual tanahnya dan/atau bangunan di bawah harga NJOP maka akan dikenakan $\mathrm{PPh}$ sesuai dengan NJOP. Jadi secara tidak langsung penjual dituntut untuk menjual tanah dan/atau bangunannya sesuai atau di atas harga NJOP, karena jika penjual melakukan penjualan tanahnya di bawah harga NJOP maka penjual itu akan mengalami kerugian. Padahal untuk tanah danatau bangunan di kawasan yang elit, jika dijual dengan harga sesuai NJOP atau di atasnya maka kemungkinan akan memerlukan waktu yang panjang, padahal kemungkinan penjual itu dalam keadaan membutuhkan uang sehingga penjual itu menjual tanah dan/atau bangunannya di bawah harga NJOP agar cepat laku.

\section{Upaya Hukum Wajib Pajak Terhadap Penetapan BPHTB dan PPh Atas Pengalihan Kepemilikan Tanah Dan Bangunan Di Bawah NJOP Upaya keberatan bea perolehan tanah dan bangunan}

Penyampaian keluhan terhadap BPHTB hanya dapat ditujukan terhadap Direktur Jenderal Pajak yang mengeluarkan surat ketetapan pajak tersebut searah dengan UU BPHTB, Wajib pajak yang akan mengajukan keberatan terhadap surat ketetapan tersebut perlu memperhatikan beberapa hal berikut:

Pertama, Keberatan dapat dilakukan pengajuan oleh pihak yang berhak, yang ditujukan terhadap Kepala Kantor Pelayanan PBB yang menerbitkan Surat Ketetapan Bea Perolehan Hak atas Tanah dan Bangunan Kurang Bayar (SKBKB), Surat Ketetapan Bea Perolehan Hak atas Tanah dan Bangunan Kurang Bayar Tambahan (SKBKBT), Surat Ketetapan Bea Perolehan Hak atas Tanah dan Bangunan Lebih Bayar (SKBLB), dan Surat Ketetapan Bea Perolehan Hak atas Tanah dan Bangunan Nihil (SKBN).

Kedua, Keberatan disampaikan lewat tertulis menggunakan bahasa Indonesia dengan menjelaskan besaran pajak yang dihutang yang sesuai dengan penghitungan wajib pajak yang disertai dalil alasan yang padat dan tepat. Dengan maksud mengemukakan dengan data dan/atau bukti tertulis yang dilampirkan yang menerangkan bahwa besarnya pajak yang terutang atau pajak yang kelebihan beri uang atau pajak kurang beri uang yang ditentukan oleh fiskus tidaklah tepat. Hal ini penting bagi fiskus dalam melakukan penelitian atas penyampaian keberatan wajib pajak sehingga jawaban keberatan sesuai dengan hal yang diminta wajib pajak. Bukti pendukung yang perlu diberitahukan oleh wajib pajak antara lain sertipikat tanah, akta jual beli, SKPT, dan surat lainnya yang dapat memberikan keterangan tentang tanah; serta IMB dan surat keterangan lainnya yang dapat mendukung keterangan tentang 
bangunan. Selain itu perlu juga dilampirkan surat atu akta yang menerangkan tentang jenis perolehan kepemilikan hak atas obyek tanah dan suatu properti yang diperoleh wajib pajak.

Ketiga, Keberatan diajukan oleh pihak yang dirugikan dalam hal pajak dengan melampirkan: a. fotokopi Surat Setoran BPHTB (SSB); b. asli SKBKBT/SKBKB/SKBN/SKBLB; c. fotokopi Risalah Lelang/Akta/Putusan Hakim/Surat Keputusan Pemberian Hak Baru; d. fotokopi SIM/ KTP/KSK/Paspor/identitas lain.

Keempat, Keberatan wajib diajukan/disampaikan dalam jarak durasi amat lambat tiga bulan mulai tanggal didapatkannya SKBKB, SKBKBT, SKBKLB, atau SKBN oleh wajib pajak, dapat dikecualikan jika wajib pajak mempunyai alasan pendukung yang dapat menjelaskan bahwa waktu yang diberikan itu belum dapat terpenuhi oleh wajib pajak karena kondisi di luar jangkauan kemampuannya. Maksudnya adalah kelebihan waktu wajib pajak tersebut melaksanakan pengajuan keluhan yang tidak disebabkan oleh kekacauannya, misalnya wajib pajak sedang terkena musibah atau sakit berat. Hal ini untuk menjamin kepastian besaran waktu wajib pajak mempergunakan haknya. Apabila wajib pajak dalam waktu 90 hari terhitung mulai pada saat memperoleh surat ketetapan pajak dan belum mengirimkan keberatan sehingga wajib pajak dikatakan membenarkan penetapan pajak yang sudah dilaksanakan oleh wajib pajak.

Kelima, Permohonan keberatan dapat disampaikan langsung kepada Kantor Pelayanan PBB setempat atau melakukan pengiriman melalui pos dengan surat tercatat. Atas pengajuan keberatan yang diterima langsung oleh fiskus dari wajib pajak, fiskus akan memberikan suatu tanda terima pengajuan keberatan. Tanda perolehan surat keluhan yang disampaikan dari pejabat Direktorat Jenderal Pajak (dalam masalah ini pegawai Kantor Pelayanan Pajak Bumi dan Bangunan) yang telah dipilih untuk itu dan/atau tanda pennyampaian/pemberian surat keluhan lewat pos yang tercatat dapat dijadikan bukti perolehan surat keluhan tersebut untuk keperluan wajib pajak.

Keenam, Tanda bukti perolehan surat keluhankeluhan tersebut dibutuhkan guna pemenuhan ketentuan peraturan tertulis. Diterima atau tidaknya hak yang telah diajukan dalam surat keluhan yang dimaksud, Dipertimbangkan pada dilaksanakannya ketntuan jangka waktu pengajuan keberatan, yang diperhitungkan semenjak dari saat dikeluarkannya atas surat ketetapan pajak sampai pada saat diperolehnya surat keluhan tersebut oleh Direktorat Jenderal Pajak.

Ketujuh, Keberatan yang tidak searah dengan peraturan yang telah berlaku tidak dapat digolongkan sebagai surat keluhan jadi surat tersebut tidak akan dapat diperhitungkan. Hal ini penting demi terjalinnya ketertiban dalam administrasi perpajakan, supaya wajib pajak yang menggunakan haknya mempunyai kewajiban untuk menaati ketentuan pengajuan keberatan.

Kedelapan, Pengajuan keberatan tidak dimaksudkan untuk menambah waktu yang diberikan sebagai keharusan penyetoran pajak dan pemenuhan pemungutan pajak. Pada dasarnya wajib pajak telah melunasi BPHTB terutang pada saat ditandatanganinya akta, risalah lelang, ataupun pada saat mendaftarkan perolehan haknya terhadap kantor pertanahan setempat. Keberatan diajukan dalam bentuk tertulis oleh wajib pajak hanya atas untuk surat ketetapan pajak yang keluar berdasarkan laporan penyetoran pajak. Karena itu jelas pengajuan keberatan tidak dimaksudkan untuk menambah waktu dalam hal kewajiban membayar pajak. Apabila ternyata wajib pajak belum melakukan pembayaran BPHTB sebagaimana mestinya maka fiskus akan melakukan penagihan pajak. Walaupun wajib pajak telah mengajukan keberatan dan sedang menunggu jawaban atas pengajuan tersebut, hal ini tidak menunda atau menghalangi fiskus untuk melakukan penagihan pajak dan wajib pajak harus membayar pajak terutang yang ditagih oleh fiskus. Bila sekiranya keluhan-keluhan wajib pajak tersebut disetujui dan terdapat sisa pembayaran pajak terutang maka sisa dalam penyetoran pajak tersebut akan diberikan kembali kepada wajib pajak. ${ }^{11}$

\section{Upaya keberatan pajak penghasilan atas pengalihan tanah dan/atau bangunan}

Wajib pajak memiliki hak untuk melakukan pengajuan keberatan/keluhan terhadap ketetapan pajak dengan melakukan penyampaian keberatan yang dibuat dalam bentuk tertulis kepada Direktur Jenderal Pajak dalam rentang waktu 3 (tiga) bulan

\footnotetext{
${ }^{11}$ Marihot Pahala Siahaan. op.cit., h. 246-248.
} 
yang terhitung dari tanggal dikirimnya surat ketetapan pajak ataupun mulai pada waktu dilakukannya pengurangan atau suatu pemungutan, dikecualikan jika wajib pajak dapat memperlihatkan bahwa rentang waktu yang ditentukan itu belum dapat terpenuhi dikarenakan suatu kondisi yang melebihi kemampuannya. ${ }^{12}$

Searah dengan Pasal 25 ayat (1) UU No. 27 Tahun 2007, Wajib pajak dapat melakukan pengajuan keluhan-keluhan hanya terhadap Direktur Jenderal Pajak terhadap suatu: 1 . Surat Ketetapan Pajak yang Kurang Bayar; 2. Surat Ketetapan Pajak yang Kurang Bayar Tambahan; 3. Surat Ketapan Pajak Nihil; 4. Surat Ketetapan Pajak Lebih Bayar; 5. pengurangan atau pengenaan pajak oleh pihak ketiga berlandaskan peraturan perundang-undangan.

Dalam Pasal 25 UU KUP, wajib pajak yang melakukan pengajuan keluhan kepada Kepala Kantor Pelayanan Pajak (KPP) di daerah wajib pajak telah terdaftar haruslah melengkapi persyaratan formal yang antara lain: 1 . Satu surat keluhan untuk bukti pengurangan/penarikan pajak atau satu ketetapan pajak; 2. Disampaikan dalam bentuk tertulis menggunakan Bahasa Indonesia; 3. Menunjukkan besaran nilai pajak yang belum terbayar atau besaran pajak yang dipungut atau dipotong, atau jumlah kerugian yang sesuai dengan analisa wajib pajak. Disertai dengan keterangan-keterangan yang dijadikan acuan analisa; 4 . Wajib pajak memiliki keharusan untuk menyetor seluruh pajak yang harus dibayarkan dengan minimal dari nilai pajak yang telah disepakati oleh wajib pajak dalam penjelasan terakhir dari hasil investigasi; 5. Disampaikan dengan maksimal 3 (tiga) bulan bermula diantarkannya surat tentang ketetapan pajak atau teritung mulai tanggal pemungutan atau pemotongan pajak; 6 . Surat keluhan wajib disertai dengan surat kuasa khusus dalam hal surat keluhan dibubuhi tanda tangan bukan oleh wajib pajak searah dengan Pasal 32 UU KUP.

Permohonan keberatan yang dilakukan suatu pengajuan oleh wajib pajak ditentukan oleh Dirjen Pajak dalam rentang waktu dua belas bulan yang terhitung dari tanggal surat keberatan diperolehnya. Keputusan Dirjen Pajak atas keberatan/keluhan dapat berupa suatu keputusan yang menerima sebagian atau seluruhnya, penambahan nilai pajak yang terutang

${ }^{12}$ Diana Sari. (2013). Konsep Dasar Perpajakan. Bandung: Refika Aditama, h. 250. atau menolak. Jika rentang waktu 12 (dua belas) bulan tersebut terlewat dan Dirjen Pajak belum memberi jawaban atas keberatan/keluhan yang disampaikan oleh wajib pajak, maka keluhan yang dikirimkan oleh wajib pajak dapat dianggap dikabulkan.

\section{Upaya hukum banding}

Berdasarkan Pasal 1 angka 6 UU No. 14 Tahun 2002, pengertian banding yakni suatu proses dalam dunia hukum yang dapat dilaksanakan oleh wajib pajak atau penjamin pajak yang ditujukan kepada suatu keputusan yang dapat dilakukannya upaya banding didasarkan peraturan-peraturan mengenai perpajakan. Upaya banding ini merupakan kepanjangan dari upaya hukum keberatan, jika wajib pajak belum dapat menerima atau belum merasa lega dengan ketentuan yang dikeluarkan oleh fiskus, wajib pajak masih memiliki suatu kesempatan untuk memperoleh keadilan dengan cara mengemukakan banding. Terhadap surat keputusan keluhan yang dikeluarkan akan dijadikan dasar untuk diajukan upaya hukum banding yang ditujukan terhadap Pengadilan Pajak searah dengan UU No. 14 Tahun 2002. ${ }^{13}$ Pengajuan banding yang ditujukan Pengadilan Pajak yang dilakukan oleh subyek pajak harus memenuhi persyaratan sebagai berikut:

Pertama, Banding yang dilaksanakan oleh wajib pajak atau penjamin pajak dengan Surat Banding menggunakan bahasa Indonesia yang ditujukan pada Pengadilan Pajak. Kedua, Banding dapat disampaikan dalam rentang waktu 3 bulan yang terhitung mulai pada waktu diperolehnya suatu keputusan yang ditujukan untuk banding, selain ditentukan yang lain dalam peraturan yang mengatur perpajakan. Yang dimaksud dengan selang waktu 3 (tiga) bulan terhitung dari waktu diterimanya keputusan keberatan sampai dengan tertanggalnya surat upaya banding yang diberikan oleh pemohon. Sebagai contoh, keputusan yang dibanding diperoleh tanggal 11 Juli 2018, sehingga batasan terakhir pemberian Surat Banding yakni tanggal 10 Oktober 2018. Ketiga, Batas waktu untuk pengajuan banding tersebut tidak mengikat jika dalam selang waktu dimaksudkan belum bisa terpenuhi dikarenakan kondisi di luar kemampuan pemohon banding. Pada dasarnya rentang waktu untuk pengajuan banding

${ }^{13}$ Wirawan B. Ilyas dan Richard Burton. (2013). Hukum Pajak (Edisi Keenam). Jakarta: Salemba, h. 114. 
(3 bulan mulai diperolehnya keputusan yang dibanding) dimaksudkan supaya pemohon banding dapat mempunyai waktu yang tidak kurang untuk melaksanakan persiapan banding beserta alasanalasan yang mendukung keberatan pemohon. Apabila dalam jangka waktu dimaksud belum dapat terpenuhi oleh pemohon banding dikarenakan kondisi yang melebihi kemampuannya (force majeur), maka rentang waktu tersebut dapat diperhitungkan/ ditentukan kembali oleh hakim tunggal atau majelis hakim Pengadilan Pajak. Keempat, Terhadap 1 (satu) keputusan hanya dapat disampaikan 1 (satu) surat upaya banding. Kelima, Banding yang diajukan wajib dibarengi dengan dalil-dalil yang padat, dan dituliskan tanggal diterimanya surat keputusan yang dibanding. Keenam, Pada surat banding harus diberikan juga salinan keputusan yang dimohonkan banding. Ketujuh, Selain dari peraturan sebagai halnya dijelaskan di atas, pada halnya banding yang disampaikan terhadap besarnya nilai jumlah pajak yang belum terbayarkan, banding tersebut cuma dapat dilakukan pengajuan jika angka yang belum terbayar tersebut telah dilakukan pembayaran minimal 50\%.

\section{PENUTUP}

\section{Kesimpulan}

Pembayaran pajak BPHTB dan PPh didasarkan pada NJOP jika NJOP lebih tinggi dari nilai tranksaksi. NJOP ditetapkan berdasarkan Surat Keputusan Kepala Daerah. UU BPHTB mengatur jika NJOP lebih besar dari angka tranksaksi maka yang dijadikan dasar pemungutan pajak adalah NJOP tersebut. Wajib pajak yang merasa mengalami ketidakadilan dalam pemungutan pajak dengan mekanisme tersebut dapat mengajukan keberatan melalui Kantor Pelayanan $\mathrm{PBB}$, sedangkan pengajuan keberatan terhadap $\mathrm{PPh}$ dapat diajukan dalam bentuk tertulis yang ditujukan terhadap Dirjen Pajak. Apabila Surat Keputusan Keberatan yang diterbitkan oleh pejabat yang berwenang belum sesuai dengan yang diharapkan oleh wajib pajak atas keluhan yang diajukan, maka wajib pajak bisa melakukan upaya banding kepada Pengadilan Pajak, karena putusan yang dikeluarkan oleh pejabat yang berwenang tersebut bukan putusan akhir, tetapi putusan Pengadilan Pajak adalah putusan yang akhir dan telah memiliki kekuatan hukum yang tetap. Namun sistem peradilan yang berakhir pada Mahkamah Agung tetaplah berjalan yakni searah dengan peraturan Pasal 91 UU Pengadilan Pajak dengan diberikan potensial wajib pajak menyampaikan upaya hukum peninjauan kembali terhadap Mahkamah Agung.

\section{Rekomendasi}

Pemerintah diharapkan mengeluarkan kebijakan baru terhadap penjualan tanah di bawah harga NJOP guna menghindari ketidakadilan dalam pemungutan pajak BPHTB dan $\mathrm{PPh}$ terhadap penjualan tanah dari bawah harga NJOP dalam praktek jual beli tanah di bawah harga NJOP sehingga mempermudah masyarakat dalam proses jual beli tanah sebagai aset. Kebijakan baru tersebut dapat dituangkan dalam bentuk peraturan perundang-undangan baru ataupun dengan cara merevisi UU BPHTB dengan menambahkan pasal baru mengenai ketentuan penjualan tanah di bawah harga NJOP, revisi tersebut selanjutnya dapat diikuti dengan revisi PP Nomor 34 Tahun 2016 sebagai peraturan pelaksana.

Pemerintah hendaknya juga dapat mengadakan penyuluhan kepada masyarakat yang masih kurang memahami mengenai jual beli tanah di bawah harga NJOP sehingga masih sering terjadi problematika hukum. Penyuluhan tersebut termasuk pula pemahaman opsi upaya hukum yang dapat ditempuh oleh para pihak yang merasa dirugikan.

\section{DAFTAR PUSTAKA}

\section{Peraturan Perundang-undangan:}

Undang-Undang Dasar Negara Republik Indonesia Tahun 1945 .

Undang-Undang Republik Indonesia Nomor 5 Tahun 1960 tentang Peraturan Dasar Pokok-Pokok Agraria.

Undang-Undang Republik Indonesia Nomor 12 tahun 1994 tentang Pajak Bumi dan Bangunan.

Undang-Undang Republik Indonesia Nomor 19 Tahun 2000 tentang Penagihan Pajak Dengan Surat Paksa.

Undang-Undang Nomor 20 Tahun 2000 tentang Bea Perolehan Hak Atas Tanah dan Bangunan.

Undang-Undang Republik Indonesia Nomor 14 Tahun 2002 tentang Pengadilan Pajak.

Undang-Undang Republik Indonesia Nomor 36 Tahun 2008 tentang Pajak Penghasilan.

Undang-Undang Republik Indonesia Nomor 16 Tahun 2009 tentang Ketentuan Umum dan Tata Cara Perpajakan. 
Undang-Undang Nomor 28 Tahun 2009 tentang Pajak Daerah dan Retribusi Daerah.

Undang-Undang Republik Indonesia Nomor 23 Tahun 2014 tentang Pemerintah Daerah.

Peraturan Pemerintah Republik Indonesia Nomor 40

Tahun 1996 tentang Hak Guna Usaha, Hak Guna Bangunan, dan Hak Pakai Atas Tanah.

Peraturan Pemerintah Republik Indonesia Nomor 34 Tahun 2016 tentang Penghasilan atas Penghasilan dari Pengalihan Hak atas Tanah dan/atau Bangunan, dan Perjanjian Pengikatan Jual Beli atas Tanah dan/atau Bangunan Beserta Perubahannya.

\section{Buku:}

Diana Sari. (2013). Konsep Dasar Perpajakan. Bandung: Refika Aditama.

J. Davey. (1988). Pembiayaan Daerah. Jakarta: UI Press.

Mardiasmo. (1998). Perpajakan. Yogyakarta: Andi Offset.

Marihot Pahala Siahaan. (2003). Bea Perolehan Hak Atas Tanah dan Bangunan. Jakarta: PT RajaGrafindo Persada.
Peter Mahmud Marzuki. (2014). Penelitian Hukum. Cetakan IX. Jakarta: Kencana Prenada Media Group.

Rochmat Soemitro. (1986). Pajak Bumi dan Bangunan. Bandung: Eresco.

Supramono dan Theresia Woro Damayanti. (2005). Perpajakan Indonesia Mekanisme dan Perhitungan. Yogyakarta: Andi Offset.

Wirawan B. Ilyas dan Richard Burton. (2013). Hukum Pajak (Edisi Keenam). Jakarta: Salemba.

\section{Jurnal:}

Etty Rochaeti. (2012). "Perlindungan Hukum Bagi Wajib Pajak Dalam Penyelesaian Sengketa Pajak". Jurnal Hukum. Vol. 26 No. 01. Bandung: Sekolah Tinggi Bandung, h. 497.

I. Kadek Sumadi dan Naniek Noviari. (2014). "Perlindungan Hukum Wajib Pajak Dalam Sengketa Pajak (Perspektif UU No. 14 Tahun 2002)". Jurnal Ilmiah Akuntansi dan Bisnis. Vol. 9 No. 2. Bali: Universitas Udayana, h. 122. 